\title{
The sequential adsorption of gold, copper, silver, and palladium from pyrolysis solid product leach solution of waste PCBs
}

\author{
Ece Yapıcı ${ }^{\dagger}$, Aysun Özkan, Zerrin Günkaya, Müfide Banar \\ Department of Environmental Engineering, Eskişehir Technical University, 26555 Eskişehir, Turkey
}

\begin{abstract}
The aim of this study is the recovery of gold, copper, silver, and palladium from waste printed circuit boards (PCBs) by sequential adsorption with waste orange peel (OP)-derived bio-sorbents. First of all, adsorption tests on the gold and silver model solutions were carried out using native orange peels and modified orange peels by different methods in order to increase the adsorption capacity. These included saponification with sodium hydroxide, hydroxypropylation with propylene oxide, crosslinking with sodium trimetaphosphate and sodium tripolyphosphate, and acidification with citric acid. The optimum adsorption conditions were determined. Gold and silver adsorption was found appropriate to the Freundlich isotherm and pseudo-second-order model for isotherm and kinetic studies, respectively. After this, model solutions including gold, copper, silver, and palladium were prepared and the adsorption efficiencies were examined in the presence of different metals. Finally, waste printed circuit boards were pyrolyzed in a fixed bed stainless steel reactor to obtain an only-metal-containing solid product. Next, leaching of metals from the solid product was performed. For the last stage, adsorption studies on the leach solution were carried out under optimum conditions. As a result, $67.07 \%$ gold, $85.77 \%$ copper, $97.05 \%$ silver, and $75 \%$ palladium were adsorbed in total.
\end{abstract}

Keywords: Adsorption, Copper, Gold, Palladium, Silver, Waste printed circuit boards

\section{Introduction}

In recent years, electronic waste (e-waste) has become one of the most conspicuous waste groups of all the waste types. Continuous improvement in electrical and electronic equipment technology increases the consumption and circulation of such material and, as a result, the lifetime of electrical and electronic devices has been decreased. E-waste has accumulated on an enormous scale, exceeding 53.6 million metric tons in 2019 , and the quantity continues to increase [1, 2]. According to the Global E-Waste Monitor's 2020 report, the amount of e-waste is estimated to reach 74.7 million metric tons by 2030 [1]. Printed circuit boards (PCBs), which are the basic parts of electronic equipment, increase significantly with the increase of e-waste, and it is estimated that $4 \%$ of such e-waste will consist of PCBs [3].

Although PCBs are only about $4 \%$ of the total weight of e-waste, they have an important economic value due to their precious metal content. These metals are $0.04 \%$ gold $(\mathrm{Au}), 0.16 \%$ silver $(\mathrm{Ag}), 0.01 \%$ palladium (Pd) and $18.4 \%$ copper $(\mathrm{Cu})$ by weight [4]. The levels of precious metals in electronic waste vary significantly between
10-1,600 ppm Au, 200-20,000 ppm Ag, and 5-970 ppm Pd, but in most cases, it exceeds what is traditionally expected in mineral ores. A rich gold ore typically contains $0.0018 \%$ (18 ppm) gold by weight, and a typical silver ore contains $0.085 \%$ (85 ppm) silver [5]. Therefore, they can be considered as 'artificial ore'. According to a study by the US Environmental Protection Agency, the recovery of metals from e-waste has significant advantages compared to primary metal production, such as lower energy consumption and less secondary waste generation [6]. In this context, the investigation for inexpensive and efficient separation techniques to recover precious metals from secondary sources, such as waste PCBs, is important both environmentally and economically.

There have been several studies on the recovery of precious metals from waste PCBs by pyro-metallurgical, hydro-metallurgical, and bio-metallurgical processes. Compared to other separation processes, adsorption is a favorable process for metal recovery due to its lower cost, higher efficiency, and lower residue production [7]. Adsorption is an efficient and economical technology for the recovery of precious metals from secondary sources by biomass, such as bacteria, fungi, algae, and agricultural and industrial
This is an Open Access article distributed under the terms of the Creative Commons Attribution Non-Commercial License (http://creativecommons.org/licenses/by-nc/3.0/) which permits unrestricted non-commercial use, distribution, and reproduction in any medium, provided the original work is properly cited.

Copyright (C) 2022 Korean Society of Environmental Engineers
Received August 27, 2021 Accepted December 12, 2021

${ }^{\dagger}$ Corresponding author

E-mail: eceturan@eskisehir.edu.tr

Tel: +90 2223213550

ORCID: 0000-0002-7502-4862 
by-products [8], which are generally abundant and cheap as alternative adsorbents. Losev et al. [9] use pine sawdust for the extraction of precious metals like gold, palladium, and platinum (Pt) from dilute solutions of hydrochloric acid. Egg-shell membrane, which is protein-rich biomass is also used for recovery of these metals [10]. Chemically modified chitosan resin with magnetic properties was investigated for the recovery of $\mathrm{Au}$ (III) and $\mathrm{Ag}$ (I) from their aqueous solutions [11]. Polyethylenimine (PEI) modified Lagerstroemia Speciosa leaves powder (PEI-LS) as a biosorbent was efficiently applied for gold recovery from acidic solution [12]. Recovery of $\mathrm{Au}$ (III) in an aqueous hydrochloric acid medium using lemon peel has also studied, and the lemon peel was found to adsorb Au (III) highly selectively [13]. Saman et al. [14] report that lignocellulosic materials can be used as adsorbents for the adsorptive recovery of $\mathrm{Au}$ (III) ions from an aqueous solution. Taşdelen et al. [15] investigate the recovery of gold from synthetic solutions using cellulose beads treated with 2-(diethylamino) ethyl chloride hydrochloride solution (DEAE-cellulose). The results show that gold can be efficiently recovered using excessive amounts of DEAE-cellulose. Sericin and alginate particles chemically crosslinked by proanthocyanidins (SAPAS) have been successfully used for gold recovery from wastewater [7].

Among biological materials, agricultural by-products are relatively cheap and exhibit extremely high adsorption capacities. One agricultural waste material from the orange juicing industry is orange peel, which is abundant, inexpensive, and easily available [16]. Orange peel is a material composed of several constituents. Among them, pectin (galacturonic acid), hemicellulose, cellulose, and lignin acid carry various polar functional groups, including carboxylic and phenolic acid groups, which can be included in the complex of metal ions. Due to its low cost, orange peel is an attractive and inexpensive alternative for the adsorptive removal of dissolved metals [17]. Waste orange peel has a large surface area, high swelling capacity, high adsorption capacity, low cost, and easy availability according to the literature [18]. Several studies have used orange peel as an adsorbent for the removal of dye $[19,20]$, herbicides [21], and various metals [22-27].

In this study, which differs from the literature, the sequential adsorption of gold $(\mathrm{Au})$, copper $(\mathrm{Cu})$, silver $(\mathrm{Ag})$, and palladium (Pd) from waste PCBs using bio-sorbents was the aim. Waste orange peel and derivatives, which are organic waste that occur in high quantity and can only be used in animal feed in Turkey, were used as bio-sorbent. For separation of the metal components from the organic material, adsorption studies were conducted with the solid products of the pyrolysis of PCBs.

\section{Materials and Methods}

This study consists of four stages (Fig. 1). In the first stage, bio-sorbent $\mathrm{OP}$ is derived from waste orange peel (WOP) and OP is chemically modified to improve the metal sorption behavior. In the second stage, adsorption experiments are performed with bio-sorbent derivatives under various conditions using $\mathrm{Au}$ and $\mathrm{Ag}$ model solutions, with the best adsorption conditions being determined. In the third stage, model solutions including $\mathrm{Au}, \mathrm{Cu}, \mathrm{Ag}$, and $\mathrm{Pd}$, which are frequently used on waste PCBs, are prepared, and adsorption effi

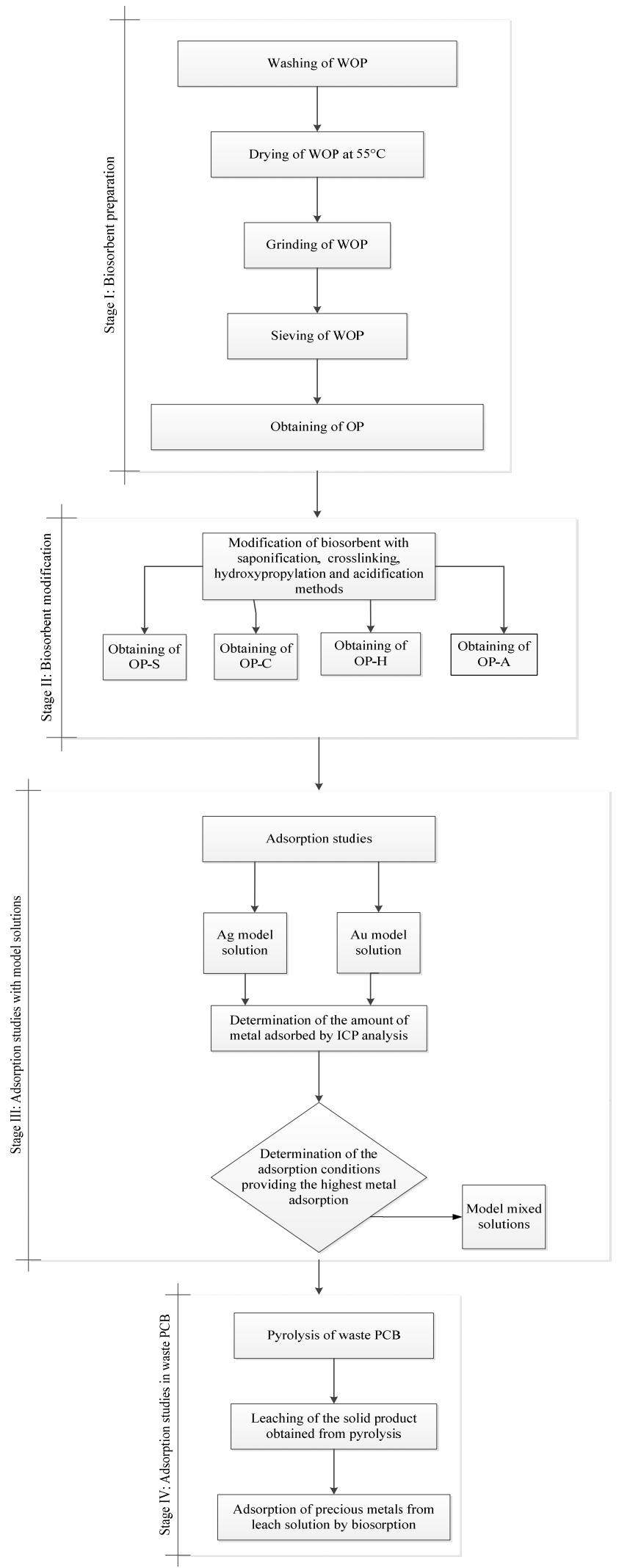

Fig. 1. Flow diagram of the study. 
ciencies are examined in the presence of different metals. Finally, the prepared PCB sample is pyrolyzed in a fixed bed stainless steel reactor to obtain an only-metal-containing solid product. After this, the leaching of metals from the solid product is performed. In the last stage, sequential adsorption studies on the leach solution of the solid product obtained from PCB pyrolysis are conducted under determined optimum conditions.

\subsection{Bio-sorbent Preparation}

To obtain OP, the WOP was washed with ultrapure water, oven-dried, ground, and sieved to a particle size of $0.2-0.5 \mathrm{~mm}$. The OP was chemically modified by saponification, crosslinking, hydroxypropylation, and acidification [28]. For saponification, $10 \mathrm{~g}$ of the $\mathrm{OP}$ was stirred with $100 \mathrm{~mL}$ of $0.1 \mathrm{M}$ sodium hydroxide $(\mathrm{NaOH})$ solution at $200 \mathrm{rpm}$ for two hours at $25^{\circ} \mathrm{C}$. It was rinsed with distilled water, and oven-dried at $55^{\circ} \mathrm{C}$ to obtain OP-S (orange peel prepared by saponification). For crosslinking, 10 $\mathrm{g}$ of the $\mathrm{OP}$ was stirred with $100 \mathrm{~mL}$ of ultrapure water containing $0.2 \mathrm{~g}$ of sodium trimetaphosphate (STMP) and $0.5 \mathrm{~g}$ of sodium tripolyphosphate (STPP) at $200 \mathrm{rpm}$ at $40^{\circ} \mathrm{C}$ for two hours. It was rinsed with distilled water, oven-dried at $55^{\circ} \mathrm{C}$ to obtain OP-C (orange peel prepared by cross-linking). For hydroxypropylation, $1.5 \mathrm{~g}$ of sodium sulfate $\left(\mathrm{Na}_{2} \mathrm{SO}_{4}\right)$ was dissolved in $100 \mathrm{~mL}$ of distilled water, $10 \mathrm{~g}$ of the $\mathrm{OP}$ was added to the solution and the $\mathrm{pH}$ was adjusted to 10.5 with $\mathrm{NaOH}$. After adding $1 \mathrm{~mL}$ of propylene oxide, the mixture was stirred at $200 \mathrm{rpm}$ at $40^{\circ} \mathrm{C}$ for twenty-four hours. It was rinsed with distilled water, oven-dried at $55^{\circ} \mathrm{C}$ to obtain $\mathrm{OP}-\mathrm{H}$ (orange peel prepared by hydroxypropylation). For acidification, $10 \mathrm{~g}$ of $\mathrm{OP}$ was stirred with $100 \mathrm{~mL}$ of $0.1 \mathrm{M}$ citric acid solution at $200 \mathrm{rpm}$ for two hours at room temperature. It was rinsed with distilled water, oven-dried at $55^{\circ} \mathrm{C}$ to obtain OP-A (orange peel prepared by acidification).

\subsection{Adsorption Studies with Model $\mathrm{Au}$ and $\mathrm{Ag}$ Solutions}

In adsorption studies, first of all, the model solutions were prepared in 10 and $25 \mathrm{mg} / \mathrm{L}$ using Fluka analytical standards for Au and $\mathrm{Ag}$, respectively. To determine the optimum $\mathrm{pH}$, preliminary experiments were carried out with a contact time of $120 \mathrm{~min}$ at two different $\mathrm{pH}$ (2 and 5), keeping the temperature and bio-sorbent type constant $\left(25^{\circ} \mathrm{C}\right.$ and $\left.\mathrm{OP}\right)$. Based on the highest adsorption efficiencies, the optimum $\mathrm{pH}$ was determined to be 2 for $\mathrm{Au}$ and 5 for Ag.

Equilibrium experiments with a sorbent concentration of 10 $\mathrm{g} / \mathrm{L}$ at different temperatures $\left(25,40\right.$, and $\left.60^{\circ} \mathrm{C}\right)$ were carried out to study the effect of temperature on $\mathrm{Au}$ and $\mathrm{Ag}$ adsorption onto OP, OP-S, OP-C, OP-H, and OP-A. $15 \mathrm{~mL}$ samples were taken every $5 \mathrm{~min}$ in the first $30 \mathrm{~min}$, and every $15 \mathrm{~min}$ in the last $90 \mathrm{~min}$. Ag concentrations of the samples were measured using a Varian ICP-OES, while Au concentrations were determined with Agilent ICP-MSMS. For Au isotherm studies, different weights of adsorbent (0.05; $0.10 ; 0.20 ; 0.30 ; 0.40$ and $0.50 \mathrm{~g}$ ) were mixed with $200 \mathrm{~mL}$ of solutions containing $10 \mathrm{mg} / \mathrm{L}$ of $\mathrm{Au}$ under constant stirring for two hours. For Ag isotherm studies, weights of adsorbent used were $0.25 ; 0.50 ; 0.75 ; 1.0 ; 1.25 ; 1.50 ; 1.75 ; 2.0$ and $2.50 \mathrm{~g}$ for 200 $\mathrm{mL}$ of $25 \mathrm{mg} / \mathrm{L} \mathrm{Ag}$ solution. The Freundlich, Langmuir, and BET models were tested [29, 30].

The pseudo-first-order, diffusion, and pseudo-second-order models were used for the analysis of exchange kinetics are represented as, respectively:

$$
\begin{gathered}
\log \left(q_{e}-q_{t}\right)=\log q_{e}-\frac{k_{l} t}{2.303} \\
q_{t}=k_{d} t^{1 / 2}+C \\
\frac{t}{q_{t}}=\frac{1}{k_{2} q_{e 2}^{2}}+\frac{1}{q_{e 2}} t
\end{gathered}
$$

where $\mathrm{k}$ is the rate constant ( $\mathrm{g} / \mathrm{mg}$ min). For the pseudo-first-order model, values of $\mathrm{k}_{1}$ and $\mathrm{q}_{\mathrm{e}}$ were derived from the linear plots of $\log \left(\mathrm{q}_{\mathrm{e}}-\mathrm{q}_{\mathrm{t}}\right)$ against $\mathrm{t}$. In the diffusion model, the values of $\mathrm{k}_{\mathrm{d}}$ and $\mathrm{C}$ were derived from the linear plots of $\mathrm{q}_{\mathrm{t}}$ against $\mathrm{t}^{1 / 2}$. Finally, for the pseudo-second-order model, the values of $\mathrm{k}_{2}$ and $\mathrm{q}_{\mathrm{e} 2}$ were derived from the linear plots of $\mathrm{t} / \mathrm{q}_{\mathrm{t}}$ against $\mathrm{t}$.

In addition, to evaluate the validity of the kinetic and isotherm models, the regression of determination coefficient $\left(R^{2}\right)$ and residual root-mean-squared error (RMSE) were calculated [31]. The RMSE equation can be expressed as follows:

$$
R M S E=\sqrt{\text { average }\left(q_{\text {exp }, n}-q_{\text {model }, n}\right)^{2}}
$$

where, $q_{\text {exp,n }}$, and $q_{\text {tcal }}(\mathrm{mg} / \mathrm{g}$ ) are the experimental results and calculated values from the model equations for the isotherm and kinetic studies, respectively. While the lower values of RMSE are considered the best estimation, the higher value $R^{2}$ is preferable in terms of good accuracy [32].

For thermodynamic properties, changes in the standard free energy $\left(\Delta \mathrm{G}^{0}\right)$, enthalpy $\left(\Delta \mathrm{H}^{0}\right)$, and entropy $\left(\Delta \mathrm{S}^{0}\right)$ were calculated using the following equations:

$$
\begin{gathered}
K_{C}=\frac{C_{A e}}{C_{S e}} \\
\Delta G^{0}=-R T \ln K_{C} \\
\ln K_{C}=\frac{\Delta S^{0}}{R}-\frac{\Delta H^{0}}{R T}
\end{gathered}
$$

where $K_{\mathrm{C}}$ is the equilibrium constant, $C_{\mathrm{Ae}}$ is the amount of $\mathrm{Au}$ and $\mathrm{Ag}$ uptake (mg/L), $C_{\mathrm{Se}}$ is the equilibrium concentrations of $\mathrm{Au}$ and $\mathrm{Ag}(\mathrm{mg} / \mathrm{L}), T$ is the temperature $(\mathrm{K})$, and $R$ is the gas constant (8.31 J/mol.K). In Eq. 6, the standard free energy was determined. A graph was prepared according to $K_{\mathrm{C}}$ and $1 / \mathrm{T}$ and $\Delta H^{\mathrm{o}}$, and $\Delta S^{\mathrm{o}}$ were calculated from the slope and intercept of this graph.

\subsection{Adsorption Studies with Model Mixed Solutions}

In this stage, two different model solutions were prepared. One of these (Model I) contained $75 \mathrm{mg} / \mathrm{L} \mathrm{Cu}, 10 \mathrm{mg} / \mathrm{L} \mathrm{Au}$ and 10 $\mathrm{mg} / \mathrm{L} \mathrm{Pd}$, and the other (Model II) included $75 \mathrm{mg} / \mathrm{L} \mathrm{Cu}, 25 \mathrm{mg} / \mathrm{L}$ $\mathrm{Ag}$, and $10 \mathrm{mg} / \mathrm{L} \mathrm{Pd}$. In experiments on the Model I and Model II mixing solutions, the adsorption processes were carried out 
sequentially. Au and Ag adsorption studies were carried out with these solutions at optimum conditions, which were obtained at the previous stage. The optimum working conditions for $\mathrm{Cu}$ and $\mathrm{Pd}$ were determined by the results from our previous studies [28, 33]. OP-C for $\mathrm{Au}$ adsorption at $\mathrm{pH} 2$ and $25^{\circ} \mathrm{C}$, OP-S for $\mathrm{Cu}$ adsorption at $\mathrm{pH}-5$ and $25^{\circ} \mathrm{C}$, and $\mathrm{OP}$ for $\mathrm{Pd}$ adsorption at $\mathrm{pH} 5$ and $60^{\circ} \mathrm{C}$ were added to the Model I solution, respectively, and mixed for 30 minutes at each stage. OP-S for $\mathrm{Cu}$ adsorption at $\mathrm{pH} 5$ and $25^{\circ} \mathrm{C}$, OP-C for $\mathrm{Ag}$ adsorption at $\mathrm{pH} 5$ and $25^{\circ} \mathrm{C}$, and $\mathrm{OP}$ for $\mathrm{Pd}$ adsorption at $\mathrm{pH} 5$ and $60^{\circ} \mathrm{C}$ were added to the Model II solution, respectively, and mixed for 30 minutes at each stage. After each stage, following the separation of the bio-sorbent by filtration from the model solutions, a $15 \mathrm{~mL}$ sample was taken and analyzed with ICP.

\subsection{Adsorption Studies in PCB Waste}

In the final stage, PCB waste was pyrolyzed under atmospheric pressure at $500^{\circ} \mathrm{C}$ with a $35^{\circ} \mathrm{C} / \mathrm{min}$ heating rate in a fixed bed stainless steel $(380 \mathrm{~S}) 240 \mathrm{~cm}^{3}$ reactor. In order to concentrate the bromine in the glass fiber contained in the PCB, zeolite was added to the PCB to be pyrolyzed at a ratio of 3:1 [34]. The metallic composition of the solid product was determined using ICP analysis.

The leaching solution was prepared by dissolving $5 \mathrm{~g}$ of pyrolysis solid product with $50 \mathrm{~mL}$ aqua regia $\left(\mathrm{HCl}\right.$ and $\left.\mathrm{HNO}_{3}\right)$. Recovery of metals from the leach solution was carried out sequentially, similar to Section 2.3. Firstly, 5 g OP-C was added to the solution at $\mathrm{pH} 2$ and $25^{\circ} \mathrm{C}$ for $\mathrm{Au}$ adsorption. After 30 minutes, the bio-sorbent was separated by filtration and it was passed to the next step. The same processes were carried out with $5 \mathrm{~g}$ OP-S at $\mathrm{pH} 5$ and $25^{\circ} \mathrm{C}$ for $\mathrm{Cu}, 5 \mathrm{~g}$ OP-C at $\mathrm{pH} 5$ and $25^{\circ} \mathrm{C}$ for $\mathrm{Ag}$, and $5 \mathrm{~g}$ OP at $\mathrm{pH} 5$ and $60^{\circ} \mathrm{C}$ for Pd. After each stage, a $15 \mathrm{~mL}$ sample was taken and analyzed with ICP.

\section{Results and Discussion}

\subsection{Equilibrium Results}

Equilibrium experiment results with the OP, OP-S, OP-C, OP-H, and $\mathrm{OP}-\mathrm{A}$ at 25,40 , and $60^{\circ} \mathrm{C}$ are given in Fig. 2. With the increase in temperature, no increase in adsorption efficiency was observed, and it was decided that the optimum temperature was $25^{\circ} \mathrm{C}$, considering low energy consumption. According to the plots, higher efficiencies are achieved in a shorter time in the Au adsorption. While the OP and OP-S efficiencies are within the range of $60-70 \%$, the $\mathrm{OP}-\mathrm{H}$ and OP-A yield is $70-80 \%$. It can be seen that OP-C is the most effective derivative in $\mathrm{Au}$ adsorption with a yield of close to $100 \%$. For $\mathrm{Ag}$, it is noteworthy that the efficiencies vary significantly (30-90\%) according to the modification types, and the lowest efficiency is observed for OP-A at all temperatures. In summary, it can be seen that the best adsorbent is $\mathrm{OP}-\mathrm{C}$ at $25^{\circ} \mathrm{C}$ for both $\mathrm{Au}$ and $\mathrm{Ag}$. Under these conditions, Au adsorption efficiency is approximately $100 \%$ and Ag adsorption efficiency is approximately $90 \%$. In addition to the remaining hydroxyl and carboxyl groups in pectin, cellulose, and lignin [28], the contribution of phosphate groups added by cross-linking in the adsorption of $\mathrm{Au}$ and Ag is obvious. However, further work should include additional analysis by FT-IR and X-ray photoelectron spectroscopy (XPS) for a clearer understanding of the metal-binding mechanism.

\subsection{Isotherm Results}

Langmuir, Freundlich, and BET isotherms plots, according to the final $\mathrm{Au}$ and Ag concentrations of different weights of OP-C, are presented in Fig. 3. In addition, Table 1 shows the values of the coefficients for these isotherm models. According to the regression coefficient values $\mathrm{R}^{2}$ in Table 1 , it may be pointed out that the adsorption isotherms can be fairly described by the Freundlich
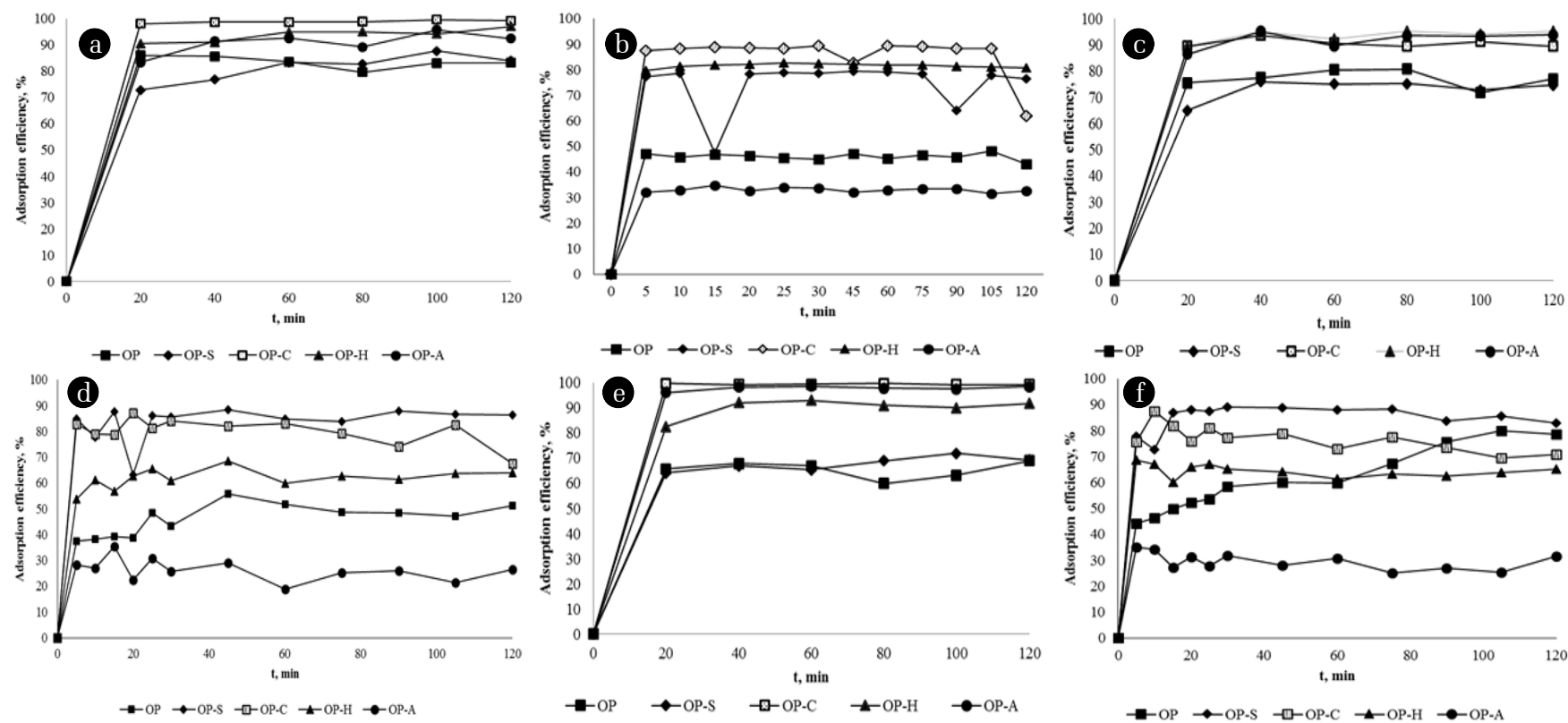

Fig. 2. Adsorption efficiencies at $25^{\circ} \mathrm{C}$ for (a) $\mathrm{Au}$ (b) $\mathrm{Ag}$, at $40^{\circ} \mathrm{C}$ for (c) $\mathrm{Au}$ (d) $\mathrm{Ag}$, at $60^{\circ} \mathrm{C}$ for (e) $\mathrm{Au}$ and (f) $\mathrm{Ag}$. 

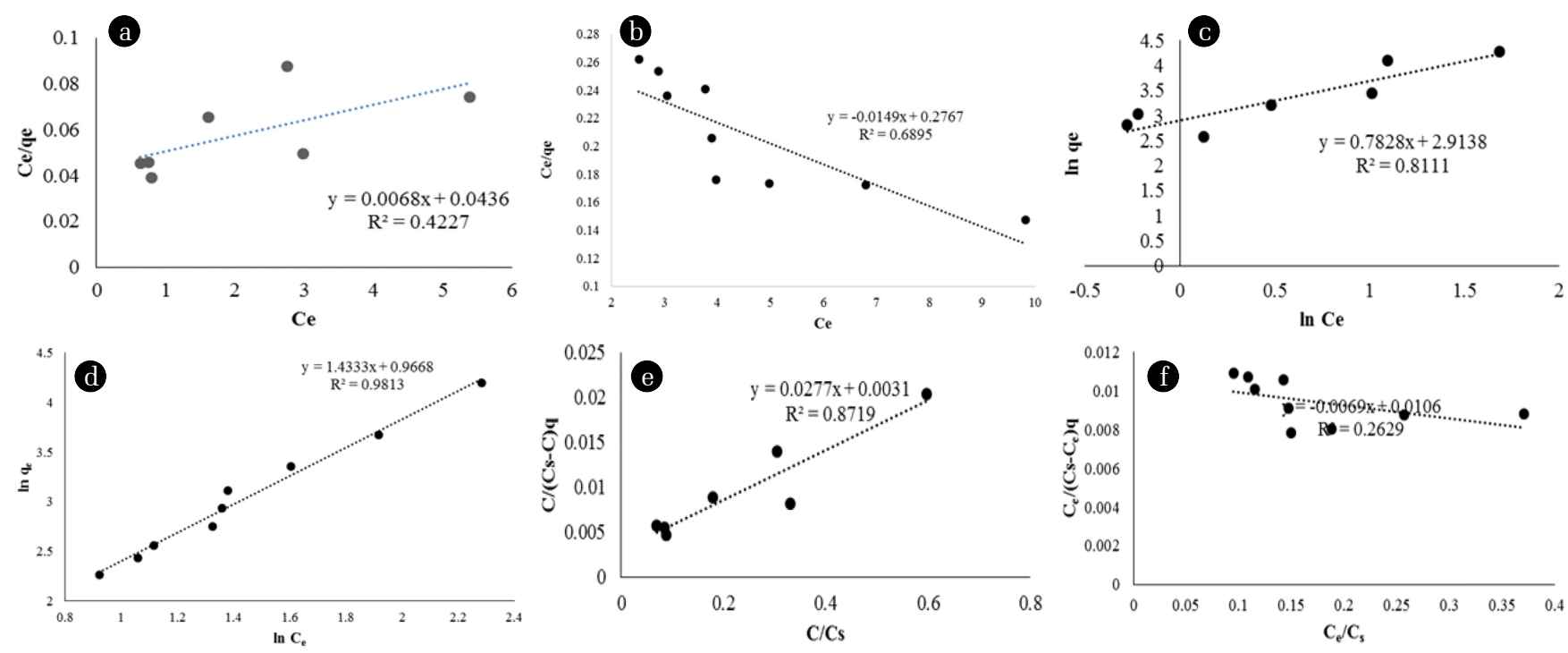

Fig. 3. Langmuir isotherm for (a) Au (b) Ag adsorption, Freundlich isotherm for (c) Au (d) Ag adsorption, and BET isotherm for (e) Au (f) Ag adsorption.

Table 1. The Parameters of the Isotherms

\begin{tabular}{lcccc}
\hline Langmuir & $\mathbf{q}_{\max }(\mathbf{m g} / \mathbf{g})$ & $\mathbf{K}_{\mathbf{L}}(\mathbf{L} / \mathbf{m g})$ & $\mathbf{R}^{2}$ & RMSE \\
\hline $\mathrm{Au}$ & 147.06 & 0.156 & 0.4227 & 7.775 \\
$\mathrm{Ag}$ & 67.11 & 0.054 & 0.6895 & 3.568 \\
\hline Freundlich & $\mathbf{1} / \mathbf{n}$ & $\mathbf{K}_{\mathbf{F}}(\mathbf{L} / \mathbf{g})$ & $\mathbf{R}^{2}$ & $\mathbf{R M S E}$ \\
\hline $\mathrm{Au}$ & 0.78 & 18.43 & 0.8111 & 7.772 \\
$\mathrm{Ag}$ & 1.43 & 2.63 & 0.9813 & 1.926 \\
\hline $\mathbf{B E T}$ & $\mathbf{q}_{\mathbf{s}}$ & $\mathbf{C}_{\text {BET }}$ & $\mathbf{R}^{2}$ & $\mathbf{R M S E}$ \\
\hline $\mathrm{Au}$ & 32.47 & 9.94 & 0.8719 & 8.183 \\
$\mathrm{Ag}$ & 270.27 & 0.35 & 0.2629 & 3.001 \\
\hline
\end{tabular}

equations for Ag and the BET equations for Au adsorption. However, high RMSE values in BET isotherms are quite remarkable. Therefore, it is possible to say that the Freundlich isotherm is suitable for both metals. The values of the Langmuir constants represent favorable conditions for adsorption, but low correlation coefficient values indicate that the Langmuir model is less suitable for the current adsorption study than others. Therefore, for the Langmuir model, $\mathrm{Ce} / \mathrm{qe}$ versus Ce is found to be highly nonlinear. Although $\mathrm{R}^{2}$ is the highest in the Freundlich isotherm for Ag, $1 / \mathrm{n}<1$ indicates that it is more successful for Au adsorption. $1 / \mathrm{n}>1$ for Ag adsorption indicates irreversible or linear adsorption [12]. The fact that $K_{f}$ has a higher value in Au adsorption supports this situation. The correlation constants are higher for the Au BET model, so that multi-layer sorption can occur during the adsorption process from Ag. This indicates that both multi-layered and heterogeneous surface conditions coexist under the applied test conditions [35]. The adsorption curves show that the maximum uptake values for $\mathrm{Au}$ and $\mathrm{Ag}$ are 72.65 and $66.75 \mathrm{mg} / \mathrm{g}$, respectively.

Additionally, the $\mathrm{q}(\mathrm{mg} / \mathrm{g})$ values were calculated using all three equations and relative errors (\%) were determined using the differences between experimental results (Fig. 4). When the graphic is carefully examined, it can be seen that the results obtained from the Freundlich model are generally closest to the real results.
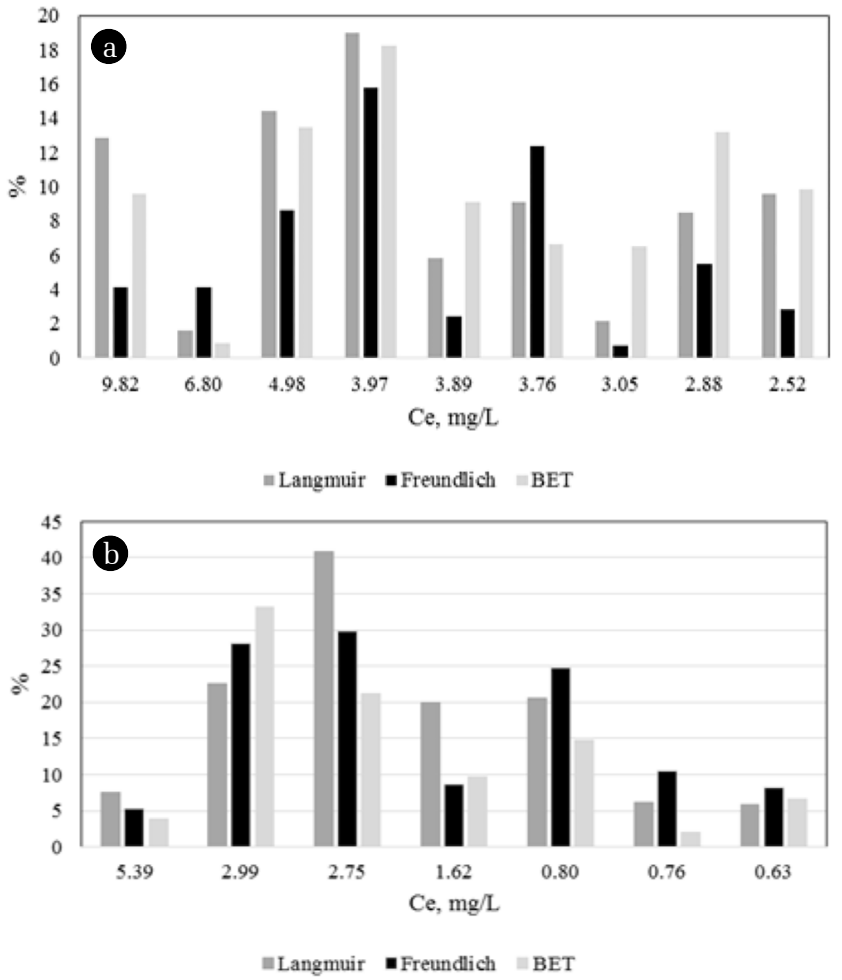

Fig. 4. Relative error (\%) plot for (a) Au and (b) Ag adsorption isotherm.

\subsection{Kinetic Results}

The kinetic model results for OP-C at $25^{\circ} \mathrm{C}$ are given in Fig. 5 . The values of the constants obtained from the linear plots are given in Table 2. According to the correlation coefficients in Table 2, the higher coefficient correlation values confirm that the $\mathrm{Au}$ and Ag uptake follows the pseudo-second-order model $\left(R^{2}>0.995\right)$. 

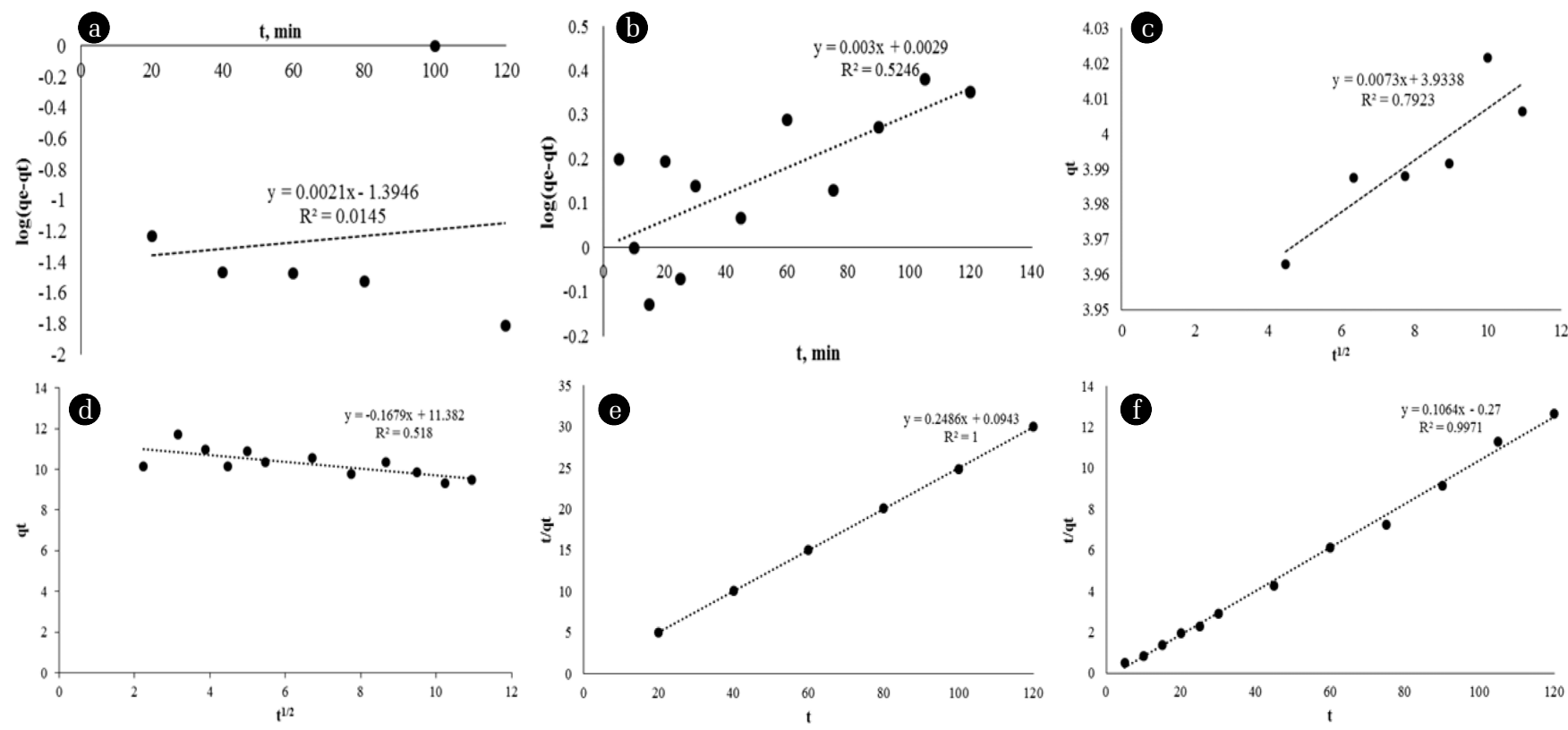

Fig. 5. Pseudo-first-order model plot for (a) Au and (b) Ag adsorption, diffusion model plot for (c) Au and (d) Ag adsorption, and pseudo-second-order model plot for (e) Au and (f) Ag adsorption.

Table 2. Kinetic Model Constants and Correlation Coefficients

\begin{tabular}{|c|c|c|c|c|}
\hline Model & & Constants & $\mathbf{R}^{2}$ & RMSE \\
\hline \multirow{2}{*}{ Pseudo first order } & $\mathrm{Au}$ & $\begin{array}{l}\mathrm{k}_{1}: 0.005 \\
\mathrm{q}_{\mathrm{e}}: 0.040\end{array}$ & 0.0145 & 0.252 \\
\hline & $\mathrm{Ag}$ & $\begin{array}{l}\mathrm{k}_{1}: 0.007 \\
\mathrm{q}_{\mathrm{e}}: 1.007\end{array}$ & 0.5246 & 0.531 \\
\hline \multirow{2}{*}{ Diffusion } & $\mathrm{Au}$ & $\begin{array}{c}\mathrm{k}_{\mathrm{d}}: 0.0073 \\
\text { C: } 3.9338\end{array}$ & 0.7923 & 0.008 \\
\hline & $\mathrm{Ag}$ & $\begin{array}{cc}\mathrm{k}_{\mathrm{d}}: & -0.1679 \\
\mathrm{C}: & 11.382\end{array}$ & 0.518 & 0.450 \\
\hline \multirow{2}{*}{ Pseudo second order } & $\mathrm{Au}$ & $\begin{array}{l}\mathrm{k}_{2}: 0.655 \\
\mathrm{q}_{\mathrm{e} 2}: 4.02\end{array}$ & 1 & 0.011 \\
\hline & $\mathrm{Ag}$ & $\begin{array}{l}\mathrm{k}_{2}: 0.042 \\
\mathrm{q}_{\mathrm{e} 2}: 9.40\end{array}$ & 0.9971 & 0.442 \\
\hline
\end{tabular}

It is noteworthy that as the $\mathrm{R}^{2}$ values increase, the RMSE values decrease in parallel. This supports that the most suitable model is the pseudo-second-order model.

\subsection{Thermodynamic Results}

The thermodynamic parameters are summarized in Table 3. The standard free energies $\left(\Delta \mathrm{G}^{0}\right)$ have negative values. These results indicate that $\mathrm{Au}$ and $\mathrm{Ag}$ adsorption by OP-C is spontaneous. $\mathrm{Ag}$ adsorption is an endothermic process, since the change in the standard enthalpy $\left(\Delta \mathrm{H}^{0}\right)$ has a positive value, while $\mathrm{Au}$ adsorption is an exothermic process. The positive value of the standard entropy change suggests that randomness increases at the solid-solution interface during adsorption. It is noteworthy that the randomness in the $\mathrm{Au}$ adsorption is higher in these results.

\subsection{Adsorption Results of Model Mixed Solutions}

According to the analysis results, while $81.01 \% \mathrm{Au}, 77.22 \% \mathrm{Cu}$, and 80.63\% Pd were totally adsorbed from the Model I solution, 94.06\% $\mathrm{Ag}, 93.41 \% \mathrm{Cu}$, and $85.88 \%$ Pd adsorption were totally performed from the Model II solution. It was observed that bio-sorbents are not selective for metals, and all metals are partially adsorbed at each stage.

\subsection{Adsorption Results from the Solid Product of the PCB Pyrolysis}

The yields of pyrolysis products in solid, liquid, and gas forms were $68.4,19.2$, and $12.4 \%$, respectively. The metallic composition of the solid product after the separation of the glass fiber part, which constitutes approximately $57 \%$, is given in Table S1. 
Table 3. Thermodynamic Parameters for Gold and Silver Adsorption with OP-C

\begin{tabular}{|c|c|c|c|c|c|}
\hline & Temperature, ${ }^{\circ} \mathrm{C}$ & $\mathbf{K}_{\mathrm{C}}$ & $\Delta \mathrm{G}^{\mathbf{0}}, \mathbf{k J} / \mathbf{m o l}$ & $\Delta \mathbf{H}^{0}, \mathbf{k J} / \mathbf{m o l}$ & $\Delta \mathbf{S}^{\mathbf{0}}, \mathrm{J} / \mathrm{mol.K}$ \\
\hline & 25 & 215.3 & -13.30 & & \\
\hline \multirow[t]{3}{*}{$\mathrm{Au}$} & 40 & 14.87 & -6.685 & -14.96 & 86.15 \\
\hline & 60 & 342.9 & -14.456 & & \\
\hline & 25 & 8.465 & -5.289 & & \\
\hline \multirow[t]{2}{*}{$\mathrm{Ag}$} & 40 & 6.800 & -4.747 & 4.440 & 2.462 \\
\hline & 60 & 6.958 & -4.804 & & \\
\hline
\end{tabular}

According to the adsorption results, in the first step, $64.21 \%$ of $\mathrm{Au}$ was recovered with $\mathrm{OP}-\mathrm{C}$ while negligible amounts of $\mathrm{Cu}$, $\mathrm{Ag}$, and Pd were also kept. In the second step, $67.01 \%$ of the $\mathrm{Cu}$ was recovered, and small amounts of $\mathrm{Au}, \mathrm{Ag}$, and Pd were kept. In the third step, $83.37 \%$ of $\mathrm{Ag}$ as the target metal was recovered, while $56.1 \%$ of the remaining $\mathrm{Cu}$ was recovered. In the last step, while $75 \%$ of the target metal Pd was recovered, $82.24 \%$ of the remaining Ag was recovered. At the end of the adsorption process, 85.77\% Cu, 67.07\% Au, 97.05\% Ag, and 75\% Pd were adsorbed in total. As a result, the findings of the $\mathrm{Au}$ and $\mathrm{Ag}$ adsorption from PCB differed from those obtained from the model solutions. This is thought to occur due to multilayer adsorption in the presence of different metals.

\section{Conclusions}

This study clearly suggests that orange waste can be converted to a valuable adsorbent. It was seen that crosslinking modification increases the Au and Ag adsorption capacity of native OP. In addition, Au and Ag recovery from PCBs was successfully realized. The adsorption equilibrium was analyzed using the Freundlich, Langmuir, and BET isotherms. The adsorption capacities of the adsorbents for $\mathrm{Au}$ and Ag recovery were compared using the calculated isotherm constants. The Freundlich isotherms provided the best modeling results for adsorption. Therefore, there may be a possibility of a multilayer, as well as heterogeneous adsorption, for Au recovery in these experimental conditions. The adsorption process of both $\mathrm{Au}$ and $\mathrm{Ag}$ onto OP-C was spontaneous $\left(-\Delta \mathrm{G}^{\circ}\right)$. Ag adsorption is an endothermic process, since the change in the standard enthalpy $\left(\Delta \mathrm{H}^{0}\right)$ has a positive value, while $\mathrm{Au}$ adsorption is an exothermic process. Moreover, the $\left(+\Delta S^{\circ}\right)$ value indicated the increased randomness at the solid-solution interface during the adsorption interaction. The sequential adsorption from pyrolysis solid product leach solution of waste PCBs resulted in a total recovery of $67.07 \% \mathrm{Au}, 85.77 \%$ $\mathrm{Cu}, 97.05 \% \mathrm{Ag}$, and $75 \% \mathrm{Pd}$. The obtained results show that orange peel and derivatives have a promising potential as an inexpensive bio-sorbent for the adsorption of precious metals from acidic leach solutions of waste PCBs. Taking account of its efficiency and low cost, orange peel could be considered as an alternative adsorbent instead of conventional adsorbents. Furthermore, recovery of the metal ions using this adsorbent could be expected to be easier.

\section{Acknowledgment}

This study was supported by the Anadolu University Scientific
Research Projects Commission, under grant No: 1503F143.

\section{Author Contributions}

E.Y. (Ph.D. student) conducted research methodology, analyses, wrote the original draft, and edited the manuscript. Z.G. (Ph.D.) conducted research methodology and edited the manuscript. A.Ö. (Ph.D.) conducted research methodology and edited the manuscript. M.B. (Ph.D.) supervised the study, reviewed and edited the manuscript.

\section{References}

1. Forti V, Balde CP, Kuehr R, Bel G. The Global E-waste Monitor 2020: Quantities, flows and the circular economy potential. United Nations University (UNU)/United Nations Institute for Training and Research (UNITAR) - co-hosted SCYCLE Programme, International Telecommunication Union (ITU) \& International Solid Waste Association (ISWA), Bonn/Geneva/ Rotterdam; 2020. p. 1-120.

2. International Telecommunication Union (ITU). Global e-waste surging: up 21 per cent in 5 years. [cited 21 November 2021]. Available from: https://www.itu.int/en/mediacentre/Pages/pr102020-global-ewaste-monitor.aspx

3. Zhang ZY, Zhang FS, Yao T. An environmentally friendly ball milling process for recovery of valuable metals from e-waste scraps. Waste Manage. 2017;68:490-497.

4. Petter PMH, Veit HM, Bernardes AM. Evaluation of gold and silver leaching from printed circuit board of cellphones. Waste Manage. 2014;34:475-482.

5. Rao MD, Singh KK, Morrison CA, Love JB. Challenges and opportunities in the recovery of gold from electronic waste. RSC Adv. 2020;10(8):4300-4309.

6. Zhang L, Xu Z. A review of current progress of recycling technologies for metals from waste electrical and electronic equipment. J. Clean. Prod. 2016;127:19-36.

7. das Graças Santos NT, Moraes LF, da Silva MGC, Vieira MGA. Recovery of gold through adsorption onto sericin and alginate particles chemically crosslinked by proanthocyanidins. J. Clean. Prod. 2020;253:119925.

8. Syed S. Recovery of gold from secondary sources - A review. Hydrometallurgy 2012;115:30-51.

9. Losev VN, Elsufiev EV, Buyko OV, Trofimchuk AK, Horda RV, Legenchuk OV. Extraction of precious metals from industrial solutions by the pine (Pinus sylvestris) sawdust-based bio- 
sorbent modified with thiourea groups. Hydrometallurgy 2018;176:118-128.

10. Maruyama T, Terashima Y, Takeda S, Okazaki F, Goto M. Selective adsorption and recovery of precious metal ions using protein-rich biomass as efficient adsorbents. Process Biochem. 2014;49(5):850-857.

11. Donia AM, Atia AA, Elwakeel KZ. Recovery of gold (III) and silver (I) on a chemically modified chitosan with magnetic properties. Hydrometallurgy 2007;87(3-4):197-206.

12. Choudhary BC, Paul D, Borse AU, Garole DJ. Surface functionalized biomass for adsorption and recovery of gold from electronic scrap and refinery wastewater. Sep. Purif. Technol. 2018;195: 260-270.

13. Parajuli D, Kawakita H, Kajiyama K, Ohto K, Harada H, Inoue K. Recovery of gold from hydrochloric acid by using lemon peel gel. Sep. Sci. Technol. 2008;43(9-10):2363-2374.

14. Saman N, Rashid MU, Lye JWP, Mat H. Recovery of Au (III) from an aqueous solution by aminopropyltriethoxysilane-functionalized lignocellulosic based adsorbents. React. Funct. Polym. 2018;123: 106-114.

15. Tasdelen C, Aktas S, Acma E, Guvenilir Y. Gold recovery from dilute gold solutions using DEAE-cellulose. Hydrometallurgy 2009;96(3):253-257.

16. Feng N, Guo X, Liang S. Adsorption study of copper (II) by chemically modified orange peel. J. Hazard. Mat. 2009;164:12861292.

17. Feng N, Guo X, Liang S. Enhanced Cu (II) adsorption by orange peel modified with sodium hydroxide. Trans. Nonferrous Met. Soc. China. 2010;20:146-152.

18. Hall WJ, Williams PT. Separation and recovery of materials from scrap printed circuit boards. Res. Conserv. Recyc. 2007;51:691-709.

19. Munagapati VS, Wen JC, Pan CL, Gutha Y, Wen JH. Enhanced adsorption performance of Reactive Red 120 azo dye from aqueous solution using quaternary amine modified orange peel powder. J. Mol. Liq. 2019;285:375-385.

20. Guediri A, Bouguettoucha A, Chebli D, Chafai N, Amrane A. Molecular dynamic simulation and DFT computational studies on the adsorption performances of methylene blue in aqueous solutions by orange peel-modified phosphoric acid. J. Mol. Struct. 2020;1202:127290.

21. Pandiarajan A, Kamaraj R, Vasudevan S, Vasudevan S. OPAC (orange peel activated carbon) derived from waste orange peel for the adsorption of chlorophenoxyacetic acid herbicides from water: adsorption isotherm, kinetic modelling and thermodynamic studies. Bioresour. Technol. 2018;261:329-341.
22. Liang S, Guo X, Feng N, Tian Q. Application of orange peel xanthate for the adsorption of $\mathrm{Pb} 2+$ from aqueous solutions. J. Hazard. Mater. 2009;170(1):425-429.

23. Sha L, Xueyi G, Ningchuan F, Qinghua T. Adsorption of Cu2+ and $\mathrm{Cd} 2+$ from aqueous solution by mercapto-acetic acid modified orange peel. Colloids. Surf. B. 2009;73(1):10-14.

24. Lasheen MR, Ammar NS, Ibrahim HS. Adsorption/desorption of $\mathrm{Cd}$ (II), $\mathrm{Cu}$ (II) and $\mathrm{Pb}$ (II) using chemically modified orange peel: Equilibrium and kinetic studies. Solid State Sci. 2012;14(2):202-210.

25. Tran HN, You SJ, Chao HP. Thermodynamic parameters of cadmium adsorption onto orange peel calculated from various methods: a comparison study. J. Environ. Chem. Eng. 2016;4(3): 2671-2682.

26. Guiza S. Biosorption of heavy metal from aqueous solution using cellulosic waste orange peel. Ecol. Eng. 2017;99:134-140.

27. Khalifa EB, Rzig B, Chakroun R, Nouagui H, Hamrouni B. Application of response surface methodology for chromium removal by adsorption on low-cost biosorbent. Chemom. Intell. Lab. Syst. 2019;189:18-26.

28. Özkan A, Günkaya Z, Yapıcı E, Banar M. Adsorption of Copper from Waste Printed Circuit Boards with Modified Orange Peels. Bioresources 2017;12(4):7283-7300.

29. Karadag D, Koc Y, Turan M, Armagan B. Removal of ammonium ion from aqueous solution using natural Turkish clinoptilolite. J. Hazard. Mat. B. 2006;136:604-609.

30. Agarwal AK, Kadu MS, Pandhurnekar CP, Muthreja IL. Langmuir, Freundlich and BET Adsorption Isotherm Studies for Zinc ions onto coal fly ash. Int. J. App. Innov. Eng. Manage. 2014;3(1):64-71.

31. Wu Z, Sun Z, Liu P, Li Q, Yang R, Yang Z. Competitive adsorption of naphthalene and phenanthrene on walnut shell based activated carbon and the verification via theoretical calculation. RSC Adv. 2020;10:10703-10714.

32. Özkan K, Işık Ş, Günkaya Z, Özkan A, Banar M. A heating value estimation of refuse derived fuel using the genetic programming model. Waste Manage. 2019;100:327-335.

33. Özkan A, Günkaya Z, Yapıcı E, Banar M. Palladium Adsorption from Printed Circuit Boards with Waste Orange Peels. Süleyman Demirel Univ. J. Nat. Appl. Sci. 2018;22(1):201-206.

34. Banar M, Özkan A, Günkaya Z, Mergen A. Pyrolysis of printed circuit board waste with the addition of certain common waste materials. Fresen. Environ. Bull. 2017;26(8):4980-4990.

35. Malik R, Ramteke DS, Wate SR. Adsorption of malachite green on groundnut shell waste based powdered activated carbon. Waste Manage. 2007;27(9):1129-1138. 